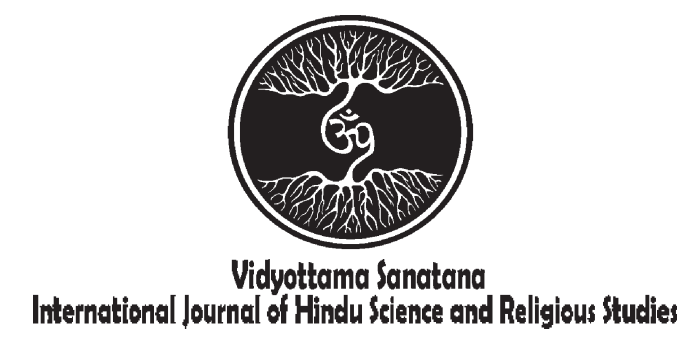

Vol. 1 No. 1 May 2017

\title{
Teaching Hinduism For The Blinds: A Study On Hinduism Teaching And Learning In SLB A Negeri Denpasar
}

By:

I Gusti Ngurah Agung Wijaya Mahardika

Institut Hindu Dharma Negeri Denpasar

Email:wijayamahardika@gmail.com

\begin{tabular}{|l|l|l} 
Received: April 25, 2017 & Accepted: May 24, 2017 & Published: May 31, 2017
\end{tabular}

\begin{abstract}
This paper focuses on the study conducted in SLB A Negeri Denpasar. The aim of the study was to identify the model of teaching used in teaching Hinduism to blind students in SLB A Negeri Denpasar. The study was conducted to the A program of SLB A Negeri Denpasar. The data were collected through observation, interview and document study. The result of the study showed that the teaching model used in teaching Hinduism was different than the teaching model used in normal school, viewed from the aspects of Syntax, Social System, Principle of Reaction, Support System, and instructional and nurturant effects of the model. The teaching model used was found to be a mix between the Direct Instruction Model and the Nondirective Teaching Model.
\end{abstract}

Key words: Teaching Model, Blind Students, SLB A N Denpasar, Special Education

\section{Introduction}

The Indonesian government defines the term education as conscious and concerted efforts to create learning atmosphere and learning process which will prompt the students to actively develop their potential in obtaining spirituality, self-control, personality, intelligence, noble characters, and skills which are needed by themselves, the society, the nation and the state (Pemerintah Republik Indonesia, 2003). The Indonesian government further guarantees the establishment of said education system, for all Indonesian citizen. This means, that the government must provide educational services for every child in Indonesia, both ordinary and students with special needs. The right to education for the students with special needs is guaranteed and protected under the sub-article 
(2) of Article 5 of the 2003 Act of National Education System, which states "citizens with special needs in terms of physical, emotional, mental and or social factor, have the rights to special education".

For the students with special needs, the government has commissioned a number of Special Education School (Sekolah Luar Biasa or SLB) throughout Indonesia. In Indonesiansetting, the history of special education school was started in Bandung, West Java in 1901. A Dutch doctor by the name of C. H. A. Westhoff established a foundation for the blind, named Vereniging tot Vernetering van het lot der Blinden in NederlandschOostIndie or the Foundation for the improvement of the blinds. The foundation was established under the Decree number 9 dated 6 August 1901 signed by then Governor General W. Roosemboom. Under this foundation, dr. Westhoff established a special school for the blind named the BandoengschBlindenInstituut under the leadership of J.W. Van der Zanden. The school was aimed at providing the blinds with work skill and experiences (Yana, 2013).

Starting from the Indonesian independence the rights to education for the blinds and other people with special needs are protected by the Indonesian laws. In the Act Number 4 of 1997 on People with Disabilities, it is stipulated in Article 5 that, "Every person with disabilities has the equal rights in all aspects of life and livelihood". Furthermore, in Article 6 sub article 1 it is stated that "every person with disabilities has the rights to education in all unit, level, and type of education. This stipulation was further explained in Act number 23 of 2002 on Child Protection, Article 51 which states that children with mental/physical disabilities have the same rights and access to education, both normal and special education. To fulfill this requirement the government established Special Education Schools throughout Indonesia (Pemerintah
Republik Indonesia, 1997; Pemerintah Republik Indonesia, 2002).

In Bali Province, especially in the city of Denpasar, there are several Special Education Schools, namely SLB A (for TunaNetra or Blindness) inJalan Serma Gede, SLB B (for TunaRungu of deafness) inJalan Pendidikan Denpasar,and SLB C (for Tuna Grahita of mental retardation) inJalan Ahmad Yani Denpasar. Out of these schools, SLB A Negeri Denpasar is the first, oldest and biggest in terms of student population. As with other students in Bali, an island which is predominantly Hindu, the students of SLBA NegeriDenpasar are mostly Hindus. Therefore, they are entitled and receive Hinduism subjectat school, just as every other Hindu student in Indonesia. Their special needs however, dictates for quite a different teaching and learning model. Which naturally will not be the same with the teaching of Hinduism for normal students. It is then interesting to identify the model of teaching used to teach Hinduism to the students in SLB A Negeri Denpasar. The identification of the teaching model will be based on Jpyce and Weil (1992) aspects of teaching model, namely the Syntax, Social System, Principle of Reaction, Support System, and instructional and nurturant effects of the model.

\section{Methods}

This study was conducted in SLB ANegeri Denpasar. SLB A Negeri Denpasar was established on 1 August 1958by Ida AyuSurayin. IdaAyuSurayin was one of the four teachers sent to the Sekolah Guru LuarBiasa (The School for Special Education Teacher) in Bandung. Upon her return to Bali, she rounded up several of her friends and established a Foundation named YayasanDriaRaba in 16 October 1957. Her first project was the establishment of a school for the blind. The school was supported by the Front Nasional Pembebasan Irian Barat Nusa Tenggara (The 
Front for the Liberation of West Papua, Nusa Tenggara Chapter) and named PantiGunaDria Raba. The school itself was inaugurated on 5 October 1959.

During the management of the school, several problems hampered the development of the school, mostly financial and education process problems. The Foundation later submitted a proposal to the Department of Education and Culture to take over the management of the school and to upgrade the school status to State School. The proposal was readily accepted by the government and the school was named SLB BagianADria Raba and officially inaugurated on 1 August 1963 with Ida AyuSurayin as the first Headmaster. The vision of the school is to provide professional and high-quality education for students with special needs.

The subjects of this study were the Hindu students and the Hinduism subject teachers of SLB A Negeri Denpasar. SLB A Negeri Denpasar comprises of two major programs based on the needs of the students, the A program is the school for the blind, and the $\mathrm{F}$ program for the students with other special needs such as ADHD and Autism. The total number of students of both programs was 131 students, consisted of 92 male students and 39 female students. The Aprogram has 47 students consisted of 31 male students and 16 female students. Meanwhile, the F program consists of 84 students comprised of 61 male students and 23 female students. The subjects of this study were the students from A(blind) program. The subjects were students from three level of education, from Elementary School, Junior High School, and Senior High School level, consisted of 12 different grades. There were $32 \mathrm{Hindu}$ students or $70 \%$ of the 47 students of SLB A Negeri Denpasar. There were 2 Hinduism subject teachers, one male, teaching in Senior
High School Level, and one female, teaching in Elementary and Junior high school level.

The study was conducted for 6 months, from June to October 2016. During the study, the data were collected using observation, interview, and document study. The data from observation were recorded in observation sheet. Meanwhile, the interview was done to the students, teachers, the headmaster, and the parents. The interviews were conducted using semi-structured interview model. The researcher started with a prepared interview questions list, but the interviewer can also obtain data by developing new questions as the interview goes.

To obtain the data on the teaching model used in teaching Hinduism, the researcher observed the teaching and learning process in the classroom as well as outside the classroom. The result of the observation was then compared to the checklist derived from Teaching Model classification by Joyce and Weil (1992). Based on the fulfillment of said checklist, the researcher was able to identify the model used by Hinduism teachers in teaching Hinduism in SLB A Negeri Denpasar. To support and triangulate the data obtained from the observation, the researcher also interviewed the teachers, the headmaster, the students, as well as the parents. The teaching model used in SLB A Negeri Denpasar was identified based on 5 aspects namely the Syntax, Social System, Principle of Reaction, Support System, and instructional and nurturant effects of the model.

The data obtained were then analyzed qualitatively. First, the data reduced by deleting unimportant, irrelevant, and redundant data. The data were then classified and the result of the classification was reordered based on the objective of the study. The conclusion was later drawn from the data. 


\section{Results And Discussion}

\subsection{Teaching model used in Teaching Hinduism}

The teaching model used in SLB ANegeri Denpasar will be described here based on five aspects, namely Syntax, Social System, Principle of Reaction, Support System, and Instructional and NurturantEffects of the model. These aspects were taken from Joyce and Weil theory of Teaching Models. By analyzing each aspect of the teaching model, the researcher hoped that a the teaching model used in SLB A Negeri Denpasar can be classified into a specific teaching model as described by Joyce and Weil.

Before continuing to the syntax, firstly, we have to consider one of the most interesting aspects of Hinduism teaching as well as every other subject in SLB A Negeri Denpasar, that the goal of the education was not limited only on academic-cognitive goal. Teachers and the headmaster admitted that due to the student's condition, ideal academic goals, such as expected from normal students, may be difficult to fulfill. Therefore, the school works on two parallel goals. The first is the academic-cognitive goal, and the second is the life skills goal. When a student is considered able to fulfill the academic-cognitive goal, the teacher will prompt said students according to their ability. Later on, said students can take the national examination and enroll in university to pursue higher education. However, if the student is considered to be having difficulty in the academic way, the teachers and school provide training of life skills that the students can use to contribute to the society in the future. The life skills taught in SLB A Negeri Denpasar are, among others, massage, Balinese traditional gamelan, Dharmagita, and other skills. This condition eventually leads to a rather relaxed and burden free, student-centered learning process which was also reflected in syntax of the teaching and learning process.
Syntax refers to the systematic steps taken by the teacher in teaching. In teaching Hinduism in SLB A Negeri Denpasar, the teachers took the following steps. The teaching process is always started with orientation phase. In this phase, the teacher provides the objectives of the learning and at the same time trying to put the current learning objectives with previous learning objectives as well as real world experiences and needs. In this step, the teacher also explains the indicators by which the success of the learning process will be measured against.

The second phase is the Presentation Phase. In this phase, the teacher delivers the content of the lesson. This is the phase which is different with Hinduism teaching for normal students. For blind students, teachers can only use lecturing technique and physical modeling. The teacher explains the lesson verbally to the students. The students take notes of the lesson using special tools to write in Braille. During the lesson, usually there is heavy traffic of question and answer. Although the students may look like they are not paying attention, i.e. sitting as they like it, in contrast to the heavily ordered seating of normal school, they really listen to the teacher's explanation. This can be seen from the way they raise questions, interrupts the teacher's explanation, and clarifying what they do not understand. Another interesting thing is that the lecturing technique which is usually a boring technique for normal students, turned out to be a captivating technique for the blind students. As for the seating, the teacher later explained that the students were given free choice of seating arrangement. Some of the students were classified as low vision, which means that the can still perceive light to some extent. These students must sit in a place where the ambient light from outside will not interfere with their study. Students also have their own preference of left or right ear to listen to the teacher, thus the students can sit wherever they like. 
The other technique used by the teacher is what I would like to call the physical modeling. This technique is used when the teacher wants to explain or train students in physical form or movement. For example, when the teacher wants to explain about the pose and hand position in Amusti Karana pose. The teacher starts with verbal explanation about the pose and hand position. The students will try to imitate the teacher's explanation in form of body movement and pose. With normal students, the teacher can simply pose in front of the class for the students to mimic. With blind students, however, this step is quite impossible. After the verbal explanation, the teachers then approach every single student and physically move and guide the students to do the movement or pose correctly. This is the part of the learning which takes a lot of time. Since the teacher will have to control the students one by one. This technique also demands constant attention and high level of patience from the teacher.

The next phase is the Check for Understanding Phase. In this phase, the teacher checks the student's understanding of the material delivered by the teacher. During the check for understanding, the teacher conducts more question and answer session to elicit information from the students and determine their grasp of the materials. There are three techniques which can be used in checking students understanding using verbal question and answer. The first technique is inviting questions from students. Again, in contrary to the students of normal schools. Students in SLB A Negeri Denpasar are very keen in asking questions, both about things that the want to know, or to clarify and or pose their understanding. This tendency makes the students question time becomes very active and lively. The second technique is by asking specific students some questions and ask the students to provide answers. Meanwhile, the third technique is by giving the students a scenario of a problem and then ask them to solve the problem by themselves. However, when the material taught is in form of poses and body movement, the teacher asks the students to pose or move based on the teacher's instruction. When the students managed to answer the teacher's questions and or move or pose as per instruction, the lesson considered to be successful.

The social system of the Hinduism Teaching model in SLB A NegeriDenpasar was more complicated than the social system of teaching in normal schools. Hinduism teacher in SLB A Negeri Denpasar were not only teachers, but they also act as counselor ad facilitator. The teacher provides counseling services to the students. They listen attentively to the student's problem and complaint. Blind students tend to rely rather heavily on the simplest communication mode that they know, the verbal communication. It is not uncommon for the students, expressing their anger, frustration, discomfort and other inconvenience by talking loudly, complaining, sometimes even shouting and yelling. Teachers, have to be extra patient when dealing with this kind of behavior. Hinduism teachers also used religious approach when dealing with upset students by providing spiritual and religious point of view regarding their complaints or discomfort.

Unlike normal schools where there arerigid principle of reactions between teacher and students, the principle of reaction in SLBA Negeri Denpasar is more relaxed and less rigid than the normal schools. Teachers act not only as teacher, but more like a colleague, a caring adult who listen to the students' problems and try their best to give solutions or at the very least, be there for the students. Based on the observation, the teachers in SLB A Negeri Denpasar, especially the Hinduism teachers were never angry. The teachers also show great appreciation to the students' achievement, even the simplest ones. Teachers also quick and generous with reinforcements, especially verbal ones. Since verbal reinforcements do not only 
appreciate student's effort for his or her own sake alone, but also helps to elevate said students position among his or her peers. Even when explaining or having academic activities and the students deviate to more personal and private problems, the teachers did not abruptly steer the class to the topic, but more like easing the class slowly.

Other than classroom meetings, the Hinduism teacher also interacts with the students outside the class during recess and also during the morning circle. The school usually starts the day with a morning circle, where they will pray together and the Hinduism teacher will deliver a short speech about universal noble values. During the observation, the students seemed to really listen to the teacher's talk, quite the contrary with the students of normal schools. In other instances, such as during the rituals held by the school or during the Hindu holy days, the students and teachers took active parts in celebrating and working in the festivals and rituals. Despite their handicap, the students of SLB A Negeri Denpasar are avid Dharmagita singers and Gamelan players. For them, singing the Dharmagita songs and playing the gamelan, are the concrete embodiment of their faith and their worship.

In order to achieve the learning objectives the students and teachers in SLB A Negeri Denpasar require special support system such as specialized tools and material. In everyday teaching and learning process, the students write and take notes using special paper which contained plastic material, which allows them to retain the markings made by the students using the specialized braille writing pen, called the Reglet and pen (slate and stylus). Since the braille system uses six dots to represent a single letter, the students need to refer to the shorthand writing of Braille known as Tusing or TulisanSingkat (literary translated into Short Writing, or shorthand). The teachers also used special paper and printer to type and print the printed materials needed for the teaching and learning process. The school obtained several Braille Embosser (printer) under a cooperation scheme between the Indonesian and the Norwegian government. Today, the school has 7 Braille Embossers consisting of Braillo 400s series and Braillo 200 series. The same scheme also provided the special paper of the Starlfors brand.

Printing the material is actually the easy part of preparing a printed material for the students. The teacher starts the complicated process from writing the material in a word processing program such as the Microsoft Word. After the material has been finalized, the teacher then has to transliterate the file using aspecial program to create a braille output of the normal file. The program used was MBC (Mitranetra Braille Converter also known as MiBee). This file was then printed using the Braille embosser. For the students, one of the most influential and useful application is the Windows Narrator. This program basically reads out the display of a screen in a computer. This program allows the students to work with computer and laptop, and recently smartphones. Students can now work with word processing software, and deliver a written account of their learning. Most of the students can even produce PowerPoint presentation for their study.

The teaching and learning process in SLB A Negeri Denpasar, especially in Hinduism subject, was not focused on academiccognitive achievement alone. Students were taught and trained to know about Hinduism and its theoretical theological foundations, but also how to really be a good Hindu. Because as stated before, the end goal of the learning is not simply passing an exam, but how to prompt the students to develop themselves for their own sake and the society. The teachers firmly believe that the result of the teaching and learning process are not limited only to academic achievement and advancement but also on how said learning process improve and expand the students' self-worth and self-confidence. Thus, 
the teaching and learning process is not just beneficial from theacademic and cognitive point of view, but also from thepsychological point of view.

Based on the above explanation, it can be concluded that the Hinduism teaching and learning process in SLB A Negeri Denpasar is quite different from the teaching learning process which take place in normal schools. It was difficult to say that the teaching model used in SLB A Negeri Denpasar as to belong to a specific model as described by Joyce and Weil (1992). The teaching model used, seems to be a mix between The Nondirective Teaching Model of the Personal Family and the Direct Instruction Model of The Behavioral System Family. Within the syntax of teaching, the steps followed the Direct Instruction Model but the goal of the education, which focuses not only on cognitive ability but also on the development self-worth and self-confidence, correspondences to the goal of the Nondirective Teaching Model. Furthermore, the non-rigid social system is in accordance with both Nondirective Teaching Model and the Direct Instruction Model. On the other hand, the principle of reaction that take place in Hinduism teaching and learning process is a mix between achieving academic goals, which is the hallmark of the Direct Instruction Model, and putting the students as the center of the process is clearly a feature of the Nondirective Teaching Model.

The reasons for the mixed model is clearly the need and condition of the students. There are steps of the Direct Instruction Model that cannot be followed through due to the students, condition. On the other hand, the features of the Nondirective Teaching Model were there because the aim of the learning is not merely an academic one. Thus, it can be said that for special needs students, a special teaching model is needed for the teaching and learning process.

\section{Conclusions}

The teaching of Hinduism in SLBA Negeri Denpasar used a unique model of teaching when compared to the model used in normal school. The Hinduism teaching model used was a mix between Direct Instruction Model and the Nondirective Teaching Model. The differences stemmed from both the condition of the students, as well as the requirements of the curriculum and the two-prongedgoals of education implemented in said school. The Hinduism education in SLB ANegeri Denpasar was not focused on academic-cognitive development alone, but also put emphasis on the development of students' self-worth and self-confidence.

\section{References}

Joyce, Bruce, R. \& Weill, Marsha. 1980. Methods of Teaching. New Jersey: Prentice-Hall.

Joyce, Bruce, R. \& Weill, Marsha. 1992. Methods of Teaching (Fourth Edition). Boston: Bacon \& Alley.

PemerintahRepublik Indonesia. 2003. UndangUndangNomor 20 Tahun 2003 TentangSistem Pendidikan Nasional. Lembaran Negara Republik Indonesia Tahun 2003 Nomor 78. Sekretariat Negara. Jakarta.

Pemerintah Republik Indonesia. 2002. Undang Undang Nomor 23 Tahun 2002 Tentang Perlindungan Anak. Lembaran Negara Republik Indonesia Tahun 2002 Nomor 109. Sekretariat Negara. Jakarta.

Pemerintah Republik Indonesia. 1997. Undang Undang Nomor 4 Tahun 1997 Tentang Penyandang Cacat. Lembaran Negara Republik Indonesia Tahun 1997 Nomor 9. Sekretariat Negara. Jakarta. 